\title{
Potential of a Khaya ivorensis - Alstonia boonei extract combination as antimalarial prophylactic remedy
}

\author{
Roselyne Nzangue Tepongning a,*, Leonardo Lucantoni ${ }^{a}$, Cinzia Carla Nasuti ${ }^{a}$, Geme Urge Dori ${ }^{a}$, \\ Serge Rakiswende Yerbanga ${ }^{\mathrm{a}}$, Giulio Lupidi ${ }^{\mathrm{a}}$, Carlotta Marini ${ }^{\mathrm{c}}$, Giacomo Rossi $^{\mathrm{c}}$, Fulvio Esposito ${ }^{\mathrm{b}}$, \\ Annette Habluetzel ${ }^{\mathrm{a}}$
}

a University of Camerino, School of Pharmacy, Piazza dei Costanti, 62032 Camerino (MC), Italy

${ }^{\mathrm{b}}$ University of Camerino, School of Science and Biotechnology, Via Gentile III Da Varano, 62032 Camerino, Italy

${ }^{\mathrm{c}}$ University of Camerino, School of Veterinary Sciences, Via Circonvallazione, 93/95 Matelica, Italy

\section{A R T I C L E I N F O}

\section{Article history:}

Received 27 April 2011

Accepted 23 June 2011

Available online 30 June 2011

\section{Keywords:}

Malaria

Plasmodium berghei

Toxicity

Khaya ivorensis

Alstonia boonei

Remedy validation

\begin{abstract}
A B S T R A C T
Ethnopharmacological relevance: The decoction of the combined stem barks of Khaya ivorensis A. Chev. (Meliaceae) and Alstonia boonei De Wild (Apocynaceae) has a history of use in traditional medicine of central Cameroon for malaria treatment but also for the prevention of the disease.

Aim of the study: The purpose of this investigation was to determine the antiplasmodial activity of Khaya ivorensis (K) and Alstonia boonei (A) preparations in the murine malaria model Plasmodium berghei/Anopheles stephensi, to estimate their prophylactic potential and to assess acute and sub-acute toxicity of the formulations prepared according to the traditional recipes.

Materials and methods: Aqueous extracts from the stem-bark of the two plants were prepared and tested separately and in combination. BALB/c mice were treated for 9 days and challenged on day 3 by exposure to mosquitoes infected with Plasmodium berghei. Treatment doses ranged between 200 and $400 \mathrm{mg} / \mathrm{kg} / \mathrm{day}$, corresponding approximately to the dosage applied by traditional healers to cure malaria patients or prevent the disease. Parasitemia reduction in treated animals was calculated from Giemsa smear counts, of two replicate experiments. To estimate acute toxicity in terms of median lethal dose (LD50), geometrically increasing doses were administered to mice. Sub-acute toxicity of the herbal combination (KA) was investigated by administering the same doses as in the antiplasmodial activity test for a period of 14 days, followed by 14 days of recovery observation. Locomotor activity (Open Field Test), body weight, liver and kidney morphology were monitored.

Results: The combination KA was found to exhibit antiplasmodial activity in the murine malaria model. In mice treated with the combination remedy at a dosage of $200 \mathrm{mg} / \mathrm{kg} / \mathrm{day}$, parasitemia values of $6.2 \% \pm 1.7$ and $6.5 \% \pm 0.8$ were recorded, compared to $10.8 \% \pm 1.3$ and $12.0 \% \pm 4.0$ in controls $(p<0.01)$. Doubling the dosage of the extracts did not significantly increase parasite suppression. When extracts of $\mathrm{K}$ and $\mathrm{A}$ were administered separately at a dosage of $400 \mathrm{mg} / \mathrm{kg}$, a reduction in parasitemia was still obtained, but it did not reach statistical significance. Toxicity studies yielded comforting results: the LD50 was estimated to be greater than $2779.5 \mathrm{mg} / \mathrm{kg}$. Moreover, mice exposed to the fourteen-day repeated-dose toxicity test (sub-acute toxicity test) did not display weight loss, liver or kidney morphological modifications, significant alterations in locomotor activity or any other sign of illness.

Conclusion: The antiplasmodial activity and the wide dose interval between the therapeutic dosage and the toxic dosage exhibited by the KA herbal combination in the murine malaria model argue in favor of its use as an antimalarial prophylactic remedy. It remains to be demonstrated by human clinical trials whether the combination remedy, when taken by inhabitants during malaria transmission season, can reduce parasite density and lead to a reduction of malaria episodes in the community.
\end{abstract}

(c) 2011 Elsevier Ireland Ltd. All rights reserved.

Abbreviations: A, Alstonia boonei; ACT, artemisinin-based combination therapy; ALT, alanine aminotransferase; ANOVA, analysis of variance; AST, aspartate amino-

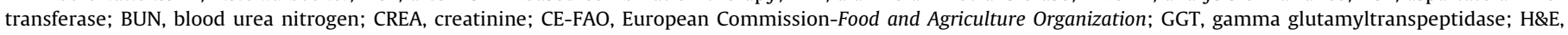

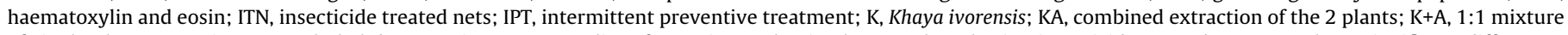

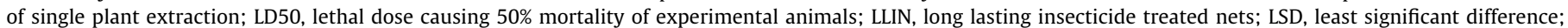

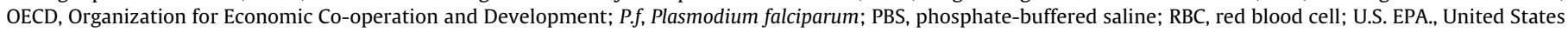
Environmental Protection Agency; WBC, white blood cell; WHO, World Health Organization.

* Corresponding author. Tel.: +39 377 1026504; fax: +39 0737403290.

E-mail addresses: roselyne.tepongning@unicam.it, rosytep@yahoo.fr (R.N. Tepongning). 


\section{Introduction}

Human development in Africa today is hampered by a number of severe infectious and parasitic diseases, among which malaria takes a sad, leading role. Worldwide, 3.3 billion people are estimated to be at risk and yearly nearly 225 million malaria cases occur, leading to the death of at least 800,000 patients in 2009 , mainly children below the age of 5 (WHO, 2010).

The situation is aggravated by the spread of drug-resistant parasite strains in many parts of the world where Plasmodium falciparum (P.f) is endemic (White, 1998, 2004; Dondorp et al., 2009).

In Cameroon, transmission of malaria occurs throughout the year and is particularly intense in the southern areas of the country. Almost 2 million cases have been registered during 2008 by the National Malaria Control Program (WHO, 2009).

To control the disease, insecticide treated bed nets and artemisinin-based combination therapy (ACT) have been adopted since 2004 as the main malaria control tools. More than 1 million insecticide treated nets (ITN) have been distributed up to now, of which about 820,000 are long lasting insecticide impregnated nets (LLIN). Clearly, this amount is not sufficient to protect the 19.4 million people at risk in the country. According to the 2009 World Malaria Report (WHO, 2009, data from 2008), about 20\% of households own at least one ITN, but only $13 \%$ of children sleep actually under a net. Moreover, approximately $59 \%$ of children with fever received treatment, but only $2 \%$ were given ACT and $6 \%$ of women received 2 or more doses of intermittent preventive treatment (IPT) during pregnancy (WHO, 2009).

As in almost all sub-Saharan endemic countries, malaria in Cameroon is particularly affecting people living in rural, remote areas, where most often affordable modern drugs are not available and where medical centres cannot assure prompt and appropriate treatment to healthcare seeking individuals. Thus, a majority of the population still relies on the use of traditional herbal medicines for the cure of malaria patients.

Based on ethnobotanical studies conducted in Cameroon, a compiled list of more than 500 traditional medicinal plants was established, including 25 antimalarial and 137 antipyretic plants (CE-FAO, 1999). Most of these plants belong to the families Acanthaceae, Myrtaceae, Rubiaceae, Cesalpinaceae, Apocynaceae or Meliaceae. Traditional preparations include concoctions, decoctions, infusions or macerations using different plant parts from one or several species (Titanji et al., 2008).

An ethnobotanical study conducted recently in the area of Mbalmayo, in the central region of Cameroon, allowed to reveal the common use of Khaya ivorensis (Meliaceae) and Alstonia boonei (Apocynaceae) as combination remedy to treat malaria but also to prevent the disease.

Khaya ivorensis and Alstonia boonei are large trees widely diffused in Central Africa. The bark, roots and leaves of both plants are traditionally used for the treatment of various types of ailments, including several infectious diseases (Idu et al., 2010).

A range of biological activities have been evidenced in extracts from different Khaya species and in some occasions have been attributed to single molecules isolated from stem-bark, leaves and roots (Zhang et al., 2009). In particular, limonoids extracted from the roots and stem bark of Khaya ivorensis have been found to exhibit antifungal activity against the pathogenic plant fungus Botrytis cinerea (Abdelgaleil et al., 2005) and to induce antiinflammatory effects in the rat paw oedema model (Agbedahunsi et al., 2004). Seed limonoids showed insect antifeeding properties against larvae of the lepidopteran Agrotis segetum (Vanucci et al., 1992) and growth inhibitory effects on the larvae of the cotton leaf worm Spodoptera littoralis (Abdelgaleil and El-Aswad, 2005).

Biological activity studies conducted with Alstonia boonei extracts derived from root-bark, stem-bark and leaves have evidenced antibacterial (Adomi and Umukoro, 2010), antiinflammatory, antipyretic and analgesic activities (Olajide et al., 2000). In Cameroon and neighboring countries, infusions prepared from Alstonia boonei stem-bark are used as an anti-venom in patients affected by snake bites or hit by poisoned arrows (Neuwinger, 1996). Alstonia boonei preparations are also known in the folk medicine as astringent, tonic and as febrifuge for malaria patients (Olajide et al., 2000; Idu et al., 2010). The major chemical constituents of Alstonia boonei include alkaloids, triterpenoids and steroids (Akinmoladun et al., 2007), and Elisabetsky and CostaCampos (2006) reported the antimalarial properties of the indole alkaloid alstonine in mice.

Given the popular use of Khaya ivorensis and Alstonia boonei as antimalarial combination remedy, information on its efficacy and safety obtained from studies with animal models is relevant to inform health providers on whether to encourage or discourage the traditional use of the plant combination. Using the murine malaria system Plasmodium berghei/Anopheles stephensi and BALB/c mice, this study aimed at (1) verifying the antiplasmodial activity of the plant combination, (2) exploring possible toxicity risks for the remedy users, and (3) assessing the potential for its prophylactic use.

\section{Material and methods}

\subsection{Plants}

Khaya ivorensis and Alstonia boonei stem bark material was collected in March 2008 in the central region of Cameroon (Mbalmayo) and identified by Mr. Victor Nana, a plant taxonomist. Voucher specimens are deposited under $\mathrm{N}^{\circ} 53957$ for Khaya ivorensis and $\mathrm{N}^{\circ}$ 43368 for Alstonia boonei at the National Herbarium of Cameroon (Yaounde).

\subsection{Preparation of plant extracts}

Fresh pieces from Alstonia boonei and Khaya ivorensis stem bark were dried at a temperature of $18-25^{\circ} \mathrm{C}$. Decoctions were prepared by boiling $50 \mathrm{~g}$ of coarsely powdered plant material in 1 litre of distilled water for $15 \mathrm{~min}$. Decoctions were then centrifuged $(10,000 \mathrm{rpm}$ for $10 \mathrm{~min})$, filtered, freeze-dried and the powders stored at $-20^{\circ} \mathrm{C}$. The yield for Khaya ivorensis (red-brown powder) and Alstonia boonei (fawn powder) were $13 \%$ and $6 \%$, respectively; the yield of the combined plant decoction was about $10 \%$.

\subsection{Experimental animals}

Female and male BALB/c mice 8-12 weeks old and weighing 20-25 g were used for this study. The experiments were carried out in the animal facility of the University of Camerino (Italy). The animals were maintained in air-conditioned rooms at a temperature of $22^{\circ} \mathrm{C}\left( \pm 3^{\circ}\right)$ and at a $12 \mathrm{~h}$ photoperiod. Animals were fed with standard rodent pellets (Mucedola s.r.l., Milano, Italy) and provided with water ad libitum. The experiments were conducted in full compliance with the European Union guidelines for experimentations on laboratory animals (Council Directive $86 / 609 /$ EEC of $24 / 11 / 86$ ) and the Italian Directive 116 of 27/10/92 on the "use and protection of laboratory animals" (licence ${ }^{\circ} 125 / 94 \mathrm{~A}$, issued by the Italian Ministry of Health).

\subsection{In vivo anti-plasmodial efficacy assessment}

\subsubsection{Murine malaria model}

A chloroquine-sensitive Plasmodium berghei ANKA strain was used to assess in vivo anti-malarial activity. The parasite strain was maintained by acyclic passages from infected to healthy BALB/c mice and cyclic passages using Anopheles stephensi mosquitoes (Lucantoni et al., 2010). 
Plasmodium berghei infection of the vector was obtained by feeding 3-5 days old Anopheles females on gametocytaemic mice. Prevalence and intensity of infection was estimated by counting developing oocysts on samples of mosquito midguts ten days after the infectious blood meal.

\subsubsection{Assessment of in vivo antiplasmodial prophylactic activity}

The dosages chosen for the assessment of antiplasmodial activity in the mouse model corresponded approximately to the amount of bark extract taken up by malaria patients according to the traditional medicine prescription. The following plant extracts, combination extracts and dosages have been tested on groups of 6 mice each:

(1) $(1: 1)$ combined extraction of the 2 plants (KA) $200 \mathrm{mg} / \mathrm{kg} / \mathrm{day} ;$ (2) $\mathrm{KA} 400 \mathrm{mg} / \mathrm{kg} / \mathrm{day}$; (3) (1:1) mixture of separate plant extracts $(\mathrm{K}+\mathrm{A}) 200 \mathrm{mg} / \mathrm{kg} /$ day $(100 \mathrm{mg} / \mathrm{kg}$ of each plant); (4) extract of Khaya ivorensis (K) $400 \mathrm{mg} / \mathrm{kg} /$ day; (5) extract of Alstonia boonei (A) $400 \mathrm{mg} / \mathrm{kg} /$ day.

The freeze-dried extracts were dissolved and diluted in distilled water. Test solutions were administered by gavage twice a day (every $12 \mathrm{~h}$ using half of the daily dosage) in volumes of $200 \mu \mathrm{L}$ for a period of 9 days. On the third day of treatment, experimental mice were individually challenged through the exposure to 10-20 bites of infective mosquitoes, $1 \mathrm{~h}$ after the first treatment of that day. Giemsa-stained thin blood smears were prepared from treated and control animals (mice treated orally with equal volumes of distilled water) 7 days after the infection of the mice. Parasitemia was determined by counting the number of parasitized erythrocytes per 3000 red blood cells. The average percent reduction of parasitemia was calculated as

\%reduction $=100 \times\left[\frac{C-T}{C}\right]$

where $C$ is the average percent parasitemia in the control group and $T$ the average percent parasitemia in the treated group.

Each experiment was performed in duplicate.

\subsection{Toxicity tests}

In accordance with the traditional way of use, $\mathrm{K}, \mathrm{A}$ and $\mathrm{KA}$ extracts were administered to experimental animals per os. BALB/c mice were used as experimental animals in the acute and sub-acute toxicity tests.

\subsubsection{Acute oral toxicity in mice}

The acute toxicity test was performed according to the method of Thompson and Weil (1952). Four geometrically increasing doses (factor 1.5 ) were chosen: $823.5 \mathrm{mg} / \mathrm{kg}, 1235.25 \mathrm{mg} / \mathrm{kg}, 1853 \mathrm{mg} / \mathrm{kg}$ and $2779.5 \mathrm{mg} / \mathrm{kg}$. Groups of five, 8-10 weeks old, male BALB/c mice, were administered a single oral treatment of $\mathrm{K}, \mathrm{A}$ and KA extracts at each dosage. The animals were observed for $48 \mathrm{~h}$ for any signs of toxicity and for behavioural changes. Body weight data were also recorded on day 0 (before extract administration), on day 7 and day 14 post-treatment.

\subsubsection{Sub-acute oral toxicity in mice}

The sub-acute toxicity was assessed by administering the combined aqueous extracts of Khaya ivorensis and Alstonia boonei (KA) at $200 \mathrm{mg} / \mathrm{kg} /$ day and $400 \mathrm{mg} / \mathrm{kg} / \mathrm{day}$, as in the prophylactic test. Treatments were continued for a period of 14 days, modifying slightly the OECD guidelines for toxicity studies in rodents (OECD 407,1995 ). Five BALB/c male mice were used per treatment group. Experimental mice were observed daily during the 14 days of treatment course and weighed every week until day 28 . Signs of toxicity were recorded. Mice that died during the test period were submitted to necropsy for anatomo-pathological inspection.
At the end of the 14 days treatment course and after the 2 weeks observation follow-up, 5 mice per group were reweighed, starved for $24 \mathrm{~h}$ and sacrificed under diethyl ether anaesthesia. The animals were dissected and their organs inspected for possible damages. Heart, lungs, spleen, liver and kidneys were removed, blotted free of blood and weighed.

2.5.2.1. Analysis of hematological and biochemical parameters. Blood was collected from diethyl ether anesthetized mice by cardiac puncture using heparinized syringes. The following blood parameters were measured using an electronic blood cell counter (Cell-Dyn 3500-Abbott): total leucocytes (WBC), neutrophils, lymphocytes, monocytes, eosinophils, basophils, red blood cells (RBC), hemoglobin, hematocrit and platelets. As biochemical parameters aspartate aminotransferase (AST), alanine aminotransferase (ALT), gamma glutamyltranspeptidase (GGT), blood urea nitrogen (BUN) and creatinine (CREA) were determined on serum samples, using an automatic biochemical analyzer (BT 3000 plus - Biotecnica instruments SPA).

2.5.2.2. Histopathological examinations. Portions of the liver and kidney from control and test animals sacrificed on day 14 and day 28 were fixed with $10 \%$ formalin in phosphate-buffered saline (PBS) for $12-24 \mathrm{~h}$, then dehydrated in ethanol series (70-95\%) and embedded in paraffin. Thin sections $(4-5 \mu \mathrm{m})$ were cut, stained with haematoxylin and eosin (H\&E) and mounted on neutral mounting medium for microscopical observation (Gabe, 1968).

2.5.2.3. Locomotor activity test (Open Field Test). An automated locomotor activity box (MedAssociates, VT 05478) was used to assess and quantify space related behavioural alterations possibly induced by the study plants (Prut and Belzung, 2003).

Mice were individually placed into the activity box $(43 \mathrm{~cm} \times 43 \mathrm{~cm} \times 30 \mathrm{~cm})$ and spontaneous locomotor activity was recorded during $5 \mathrm{~min}$, starting $1 \mathrm{~min}$ after having placed the animal in the test cage. Mouse movements were revealed by an orthogonal light beam system, classified and analyzed by the activity box software package (Activity Monitor, MedAssociates). The tests were performed $5 \mathrm{~h}$ after the last treatment. The following behavioural parameters were considered: locomotion (numbers of ambulatory episodes), rearings (numbers of vertical movements, standing up on the hind legs), stereotype counts (number of grooming movements) and number of entries into the central square of the arena. Few entries into the central area are indicative for a mouse feeling fear or being anxious (Contò et al., 2005; Levay et al., 2008). Number of ambulatory, rearing and grooming episodes in the central zone of the field were expressed as percentage of total ambulatory, vertical and stereotypic counts, respectively. Between each test session, the apparatus was cleaned with $10 \%$ ethanol and dried with a cloth to remove any mouse odours.

\subsection{Statistical analysis}

Quantitative data were expressed as arithmetic mean values \pm standard deviation/confidence interval. To compare parasitemia levels, the independent samples Student's $t$-test was used, and for the other results, one-way analysis of variance (ANOVA) followed by the least-significant difference (LSD) post hoc tests were applied.

\section{Results}

\subsection{In vivo prophylactic antiplasmodial activity}

The experimental combinations of Khaya ivorensis and Alstonia boonei (KA) were found to exhibit appreciable antiplasmodial activ- 


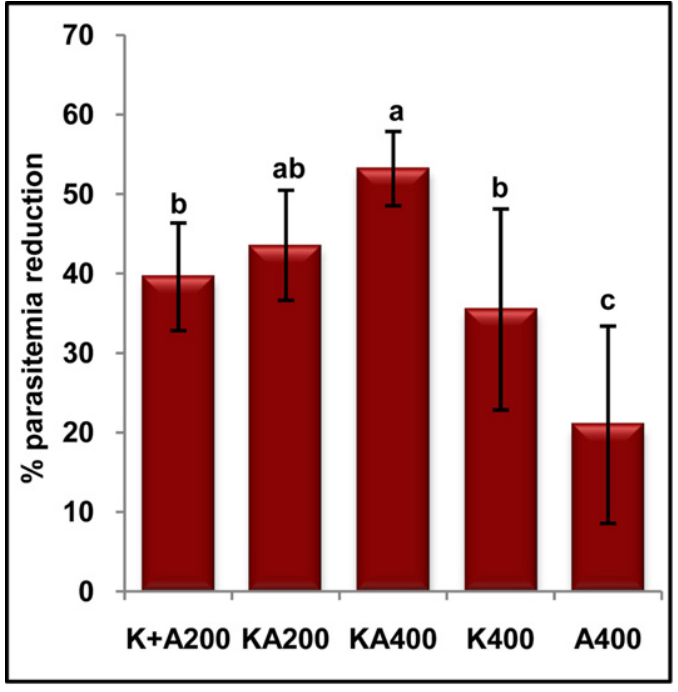

Fig. 1. Impact of prophylactic, oral administration of Khaya ivorensis and Alstonia boonei stem bark decoctions on parasitemia in mice. Extracts from the 2 plants - combined or as single plant extracts - were administered at $200 \mathrm{mg} / \mathrm{kg}$ and $400 \mathrm{mg} / \mathrm{kg}$ to groups of 6 mice each for 9 days. The infection of the mice with Plasmodium berghei was effected on day 3 of treatment by exposure to infective mosquito bites. Giemsa smears for the assessment of parasitemia were prepared on day 7 post-challenge. Means of \% parasitemia were calculated for each group. Percent reductions of parasitemia found in the treatment groups (compared to controls) are illustrated in the figure. Bars represent CI95\%. One way ANOVA followed by LSD test was performed to assess significance of differences. Different letters over the bars $(\mathrm{a}-\mathrm{c})$ evidence significant differences between the groups.

ity against Plasmodium berghei in the mouse (Fig. 1). Administered at the dosages of $200 \mathrm{mg} / \mathrm{kg} /$ day and $400 \mathrm{mg} /$ day, the KA preparation reduced parasitemia values by $43.6 \%$ and $53.2 \%$ respectively. Percent parasitemia values determined in the treatment groups ranged between $4.8 \%$ and $7.8 \%$, according to dosage and replicate experiment and amounted to $10.5-16.0 \%$ in the control groups (Table 1). Comparing the efficacy of the KA extract at $200 \mathrm{mg} / \mathrm{kg}$ with that of $\mathrm{K}+\mathrm{A}$, i.e. the $1: 1$ formulation of single plant extrac-

Table 1

Effects of Khaya ivorensis and Alstonia boonei extracts on Plasmodium berghei parasitemia.

\begin{tabular}{lllc}
\hline $\begin{array}{l}\text { Treatment } \\
\text { groups }^{\mathrm{a}}\end{array}$ & $\begin{array}{l}\text { Dose } \\
(\mathrm{mg} / \mathrm{kg} / \mathrm{day})\end{array}$ & Experiment $^{\mathrm{b}}$ & $\begin{array}{l}\text { Mean parasitemia } \\
(\%) \pm \text { S.D. }\end{array}$ \\
\hline $\mathrm{K}+\mathrm{A}$ & 200 & 1 & $7.7 \pm 1.2^{*}$ \\
$\mathrm{KA}$ & 200 & 2 & $6.2 \pm 1.5^{* *}$ \\
$\mathrm{KA}$ & 400 & 3 & $6.5 \pm 0.8^{* *}$ \\
& 400 & 4 & $6.2 \pm 1.7^{* *}$ \\
$\mathrm{~K}$ & & 5 & $4.8 \pm 1.2^{* *}$ \\
$\mathrm{~A}$ & & 6 & $7.8 \pm 0.8^{* *}$ \\
Control & $400 \mu \mathrm{L}$ & 6 & $6.7 \pm 1.6$ \\
& & 1 & $8.2 \pm 1.6$ \\
& & 2 & $12.0 \pm 4.0$ \\
& & 3 & $10.9 \pm 1.3$ \\
& & 4 & $10.5 \pm 2.8$ \\
& & 5 & $10.8 \pm 1.3$ \\
\end{tabular}

Mice $(n=6)$ were challenged by infected mosquito bites on day 3 of treatment and parasitemia (\%) was measured on day 7 post-challenge. The control groups received $400 \mu \mathrm{L} /$ day of distilled water for 9 days. Data are expressed as means \pm S.D. Independent samples Student's $t$-test was used to compare the treated and control groups.

a $\mathrm{K}+\mathrm{A}$, mixture of separate plant extracts (1:1); KA, combined extraction of the 2 plants (1:1); K, aqueous extract of Khaya ivorensis; A, aqueous extract of Alstonia boonei.

b Each number represents one experiment involving treatment and control groups of six mice each.

${ }^{*} p<0.05$.

** $p<0.01$.

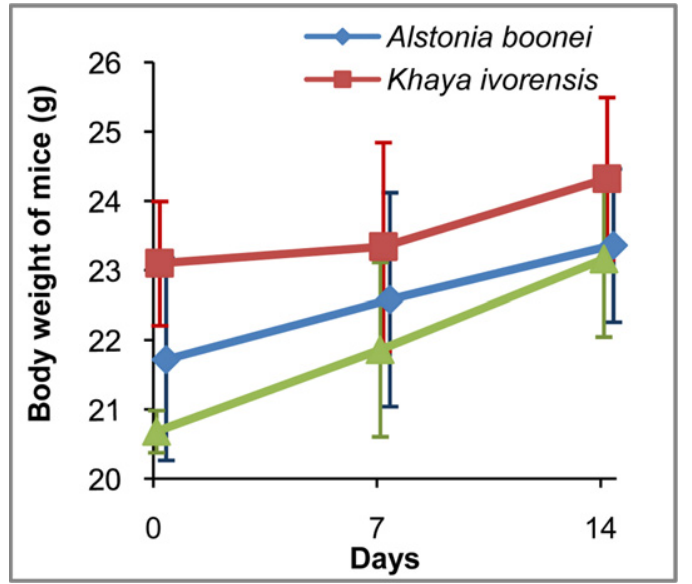

Fig. 2. Body weight pattern of mice subjected to the acute toxicity test. Groups of BALB/c mice $(n=5)$ were monitored for weight increase after oral administration with a single dose of Khaya ivorensis-Alstonia boonei combination extract or single plant preparations at the dose of $2779.5 \mathrm{mg} / \mathrm{kg}$. The mice were weighed before the treatment (day 0), at day 7 and day 14 after treatment. Weights are reported as arithmetic means, bars are indicating the S.D. The values were slightly shifted to the right to avoid overlapping of the error bars.

tions at the same dosage, similar reductions of 39.6\% (32.8-46.4\%) and $43.6 \%$ (36.6-50.5\%) were found (Fig. 1).

Doubling the KA dosage to $400 \mathrm{mg} / \mathrm{kg} /$ day resulted in a $53.2 \%$ (48.5-57.9\%) parasite reduction, not significantly higher than that observed with $\mathrm{KA}$ at $200 \mathrm{mg} / \mathrm{kg} /$ day. Administering Khaya ivorensis (K) and Alstonia boonei (A) extracts separately at the dose of $400 \mathrm{mg} / \mathrm{kg}$, resulted in relatively lower parasitemia reductions of $35.5 \%$ (22.8-48.1\%) and 21.0\% (8.6-33.4\%), respectively (Fig. 1).

\subsection{Toxicity assessment}

\subsubsection{Acute toxicity}

Oral, single dose administration of Khaya ivorensis and Alstonia boonei extracts, both, of single ( $\mathrm{K}$ and $\mathrm{A}$ ) and combined plant preparations (KA), proved to be not toxic up to a dosage of $2775.9 \mathrm{mg} / \mathrm{kg}$ (highest tested dose). No mortality and visible signs or symptoms of toxicity were observed in any of the treated animals at this nor at lower dosages. Body weight measurements in mice treated with $2775.9 \mathrm{mg} / \mathrm{kg}$ of the extracts on day 0 (before treatment), on day 7 and on day 14 , showed a weight increase of $1-2 \mathrm{~g}$ (Fig. 2), corresponding to that of healthy male BALB/C mice at the age of $8-10$ weeks (River, 2010).

\subsubsection{Sub-acute toxicity}

Animals treated with KA combination at $200 \mathrm{mg} / \mathrm{kg}$ or $400 \mathrm{mg} / \mathrm{kg}$ for 14 days remained in general good condition and no adverse effects were observed throughout the treatment period and during the 2 week follow up. Body weights recorded in the cohorts of mice monitored for the 2 week treatment period (Table 2A) and for the 4 week treatment plus follow up period (Table 2B) were similar in treated and control animals. Also, no differences were observed in weights of organs, i.e. lungs, livers, kidneys, hearts and spleens between treated and control mice, sacrificed on day 14 (Table 2 A) or on day 28 (Table 2B).

3.2.2.1. Effects on hematological and biochemical parameters. The treatment with KA extract did not show an impact on hematological parameters at the 2 tested dosages, except on the number of platelets (Table 3 ). Mice treated with KA at a concentration of $400 \mathrm{mg} / \mathrm{kg}$ for 14 days and bled on day 28 exhibited a mean platelet count of $260,800 \mu \mathrm{L}^{-1} \pm 107,900$, whereas untreated animals and mice treated with KA $200 \mathrm{mg} / \mathrm{kg}$ showed mean values 
Table 2

Body and organ weights of mice subjected to KA sub-acute toxicity assessment of the Khaya ivorensis-Alstonia boonei combination.

\begin{tabular}{|c|c|c|c|c|c|}
\hline \multirow[t]{2}{*}{ Groups } & & \multicolumn{3}{|c|}{ Body weight $(\mathrm{g}) \pm$ S.D. } & \\
\hline & & Day 0 & Day 7 & \multicolumn{2}{|l|}{ Day 14} \\
\hline \multicolumn{6}{|c|}{ (A) Mice monitored for the 2 weeks treatment and sacrificed at day 14} \\
\hline Control & & $24.0 \pm 1.4$ & $23.5 \pm 1.8$ & \multicolumn{2}{|l|}{$24.3 \pm 2.1$} \\
\hline $\mathrm{KA} 200 \mathrm{mg} / \mathrm{kg}$ & & $23.8 \pm 0.8$ & $23.3 \pm 0.8$ & \multicolumn{2}{|l|}{$23.6 \pm 1.1$} \\
\hline $\mathrm{KA} 400 \mathrm{mg} / \mathrm{kg}$ & & $24.9 \pm 2.1$ & $23.6 \pm 2.1$ & $24.4 \pm 1.6$ & \\
\hline \multirow[t]{2}{*}{ Groups } & \multicolumn{5}{|c|}{ Organ weight $(\mathrm{g}) \pm$ S.D. at day 14} \\
\hline & Liver & Kidneys & Heart & Spleen & Lungs \\
\hline Control & $0.89 \pm 0.12$ & $0.34 \pm 0.05$ & $0.16 \pm 0.03$ & $0.14 \pm 0.02$ & $0.06 \pm 0.01$ \\
\hline $\mathrm{KA} 200 \mathrm{mg} / \mathrm{kg}$ & $0.92 \pm 0.04$ & $0.36 \pm 0.02$ & $0.16 \pm 0.03$ & $0.13 \pm 0.02$ & $0.07 \pm 0.01$ \\
\hline $\mathrm{KA} 400 \mathrm{mg} / \mathrm{kg}$ & $0.94 \pm 0.07$ & $0.36 \pm 0.04$ & $0.15 \pm 0.01$ & $0.14 \pm 0.02$ & $0.07 \pm 0.01$ \\
\hline \multirow[t]{2}{*}{ Groups } & \multicolumn{5}{|c|}{ Body weight $(g) \pm$ S.D. } \\
\hline & Day 0 & Day 7 & Day 14 & Day 21 & Day 28 \\
\hline \multicolumn{6}{|c|}{ (B) Mice monitored for the 2 weeks treatment and 2 weeks follow up, sacrificed at day 28} \\
\hline Control & $24.0 \pm 1.3$ & $23.9 \pm 1.3$ & $24.6 \pm 0.9$ & $25.0 \pm 1.5$ & $25.9 \pm 1.4$ \\
\hline $\mathrm{KA} 200 \mathrm{mg} / \mathrm{kg}$ & $24.2 \pm 0.8$ & $24.2 \pm 0.5$ & $24.5 \pm 0.5$ & $24.6 \pm 1.3$ & $25.5 \pm 1.5$ \\
\hline $\mathrm{KA} 400 \mathrm{mg} / \mathrm{kg}$ & $24.7 \pm 1.7$ & $23.9 \pm 2.0$ & $23.5 \pm 2.4$ & $24.9 \pm 1.6$ & $25.4 \pm 1.6$ \\
\hline \multirow[t]{2}{*}{ Groups } & \multicolumn{5}{|c|}{ Organ weight $(\mathrm{g}) \pm$ S.D. at day 28} \\
\hline & Liver & Kidneys & Heart & Spleen & Lungs \\
\hline Control & $1.11 \pm 0.10$ & $0.41 \pm 0.03$ & $0.14 \pm 0.01$ & $0.16 \pm 0.03$ & $0.08 \pm 0.02$ \\
\hline $\mathrm{KA} 200 \mathrm{mg} / \mathrm{kg}$ & $1.11 \pm 0.09$ & $0.41 \pm 0.04$ & $0.15 \pm 0.02$ & $0.15 \pm 0.03$ & $0.08 \pm 0.01$ \\
\hline $\mathrm{KA} 400 \mathrm{mg} / \mathrm{kg}$ & $1.13 \pm 0.15$ & $0.40 \pm 0.03$ & $0.14 \pm 0.02$ & $0.16 \pm 0.02$ & $0.08 \pm 0.00$ \\
\hline
\end{tabular}

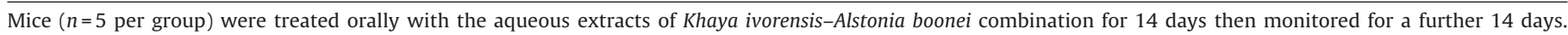
Arithmetic means and \pm S.D. were calculated from body and organ weight measurements.

Table 3

Hemogram of mice subjected to sub-acute toxicity of the Khaya ivorensis-Alstonia boonei combination (KA).

\begin{tabular}{lccc}
\hline Parameters & Control & KA $200 \mathrm{mg} / \mathrm{kg}$ & KA $400 \mathrm{mg} / \mathrm{kg}$ \\
\hline RBC $\left(\times 10^{12} / \mathrm{L}\right)$ & $10.3 \pm 0.2$ & $10.4 \pm 0.4$ & $8.6 \pm 3.2$ \\
Hemoglobin $(\mathrm{g} / \mathrm{dL})$ & $15.9 \pm 0.6$ & $15.4 \pm 0.5$ & $15.4 \pm 0.8$ \\
Hematocrit $(\%)$ & $43.4 \pm 0.5$ & $42.0 \pm 15$ & $36.7 \pm 13.6$ \\
Platelets $\left(\times 10^{9} / \mathrm{L}\right)$ & $458.3 \pm 80.4^{\mathrm{a}}$ & $526.5 \pm 99.7^{\mathrm{a}}$ & $260.8 \pm 107.9^{\mathrm{b}}$ \\
WBC $\left(\times 10^{9} / \mathrm{L}\right)$ & $1.7 \pm 0.6^{\mathrm{A}}$ & $1.4 \pm 0.5$ & $1.1 \pm 1.1$ \\
Neutrophiles $(\%)$ & $22.2 \pm 9.9$ & $22.1 \pm 5.3$ & $34.6 \pm 20.6$ \\
Lymphocytes $(\%)$ & $71.3 \pm 49.8$ & $73.9 \pm 41.0$ & $57.2 \pm 100$ \\
Monocytes $(\%)$ & $2.6 \pm 2.4$ & $1.4 \pm 0.3$ & $3.0 \pm 1.7$ \\
Eosinophiles $(\%)$ & $0.6 \pm 0.7$ & $0.9 \pm 0.5$ & $1.0 \pm 0.6$ \\
Basophiles $(\%)$ & $3.4 \pm 3.8$ & $1.9 \pm 1.1$ & $4.5 \pm 2.2$ \\
\hline
\end{tabular}

Blood samples were collected from treated and control mice (5 mice per group) on day 28 of the sub-acute toxicity experiment (14 days after the end of treatments).

A Values are expressed as means \pm S.D. One way ANOVA and LSD test were used. Different letters ( $a$ and $b$ ) represent significant differences between groups. of $458,300 \mu \mathrm{L}^{-1} \pm 80,400$ and $526,500 \mu \mathrm{L}^{-1} \pm 99,700$, respectively (LSD test, $p<0.05$ ).

Biochemical parameters, indicative for tissue damage or interference with the organ functionality of liver and kidneys, were found to be increased in treated mice compared to controls at day 14, after 2 weeks of treatment (Table 4). The liver enzyme values AST, ALP and GGT and the kidney markers BUN and CREA from KA extract treated mice at $200 \mathrm{mg} / \mathrm{kg}$ and at $400 \mathrm{mg} / \mathrm{kg}$ were significantly higher than the values of controls $(p<0.05)$, with the exception of the AST value of mice treated at the concentration of $400 \mathrm{mg} / \mathrm{kg}$. At the end of the 2 weeks follow up period (day 28), treated and control mice showed similar values of all monitored biochemical parameters.

3.2.2.2. Histopathological examinations. No tissue damage or morphological alterations were evident at necropsy of the mice which have been treated with KA for 14 days and examined at the end of the treatment period or at the end of the follow up period. Also, microscope examination of liver and kidney sections from treated

Table 4

Biochemical parameters of mice subjected to sub-acute toxicity assessment of the Khaya ivorensis - Alstonia boonei combination (KA).

\begin{tabular}{|c|c|c|c|c|}
\hline Parameters & Tested at & Control & $\mathrm{KA} 200 \mathrm{mg} / \mathrm{kg}$ & $\mathrm{KA} 400 \mathrm{mg} / \mathrm{kg}$ \\
\hline $\operatorname{AST}(\mathrm{u} / \mathrm{L})$ & Day 14 & $78.9 \pm 26.5^{\mathrm{A}, \mathrm{a}}$ & $198.9 \pm 93.1^{b}$ & $113.0 \pm 24.4^{\mathrm{a}}$ \\
\hline $\operatorname{ALT}(\mathrm{u} / \mathrm{L})$ & & $21.5 \pm 5.7^{\mathrm{a}}$ & $41.2 \pm 12.0^{\mathrm{b}}$ & $36.2 \pm 8.0^{\mathrm{b}}$ \\
\hline GGT (u/L) & & $3.6 \pm 0.7^{\mathrm{a}}$ & $7.8 \pm 1.4^{\mathrm{b}}$ & $6.9 \pm 1.8^{\mathrm{b}}$ \\
\hline BUN (mg/dL) & & $30.5 \pm 11.8^{\mathrm{a}}$ & $57.9 \pm 27.0^{b}$ & $59.3 \pm 25.7^{b}$ \\
\hline CREA (mg/dL) & & $0.26 \pm 0.04^{\mathrm{a}}$ & $0.55 \pm 0.10^{\mathrm{b}}$ & $0.49 \pm 0.04^{b}$ \\
\hline $\operatorname{AST}(\mathrm{u} / \mathrm{L})$ & Day 28 & $290.2 \pm 117.7$ & $222.6 \pm 69.7$ & $249.0 \pm 45.1$ \\
\hline $\operatorname{ALT}(\mathrm{u} / \mathrm{L})$ & & $56.8 \pm 12.9$ & $56.8 \pm 14.6$ & $58.0 \pm 11.8$ \\
\hline GGT $(\mathrm{u} / \mathrm{L})$ & & $10.7 \pm 12.3$ & $5.8 \pm 6.3$ & $3.5 \pm 2.5$ \\
\hline BUN (mg/dL) & & $65.2 \pm 27.4$ & $68.6 \pm 20.8$ & $98.9 \pm 58.5$ \\
\hline CREA (mg/dL) & & $0.59 \pm 0.15$ & $0.59 \pm 0.09$ & $0.69 \pm 0.33$ \\
\hline
\end{tabular}

Blood samples were collected from treated and control mice (5 mice per group) on days 14 and 28 of the sub-acute toxicity experiment.

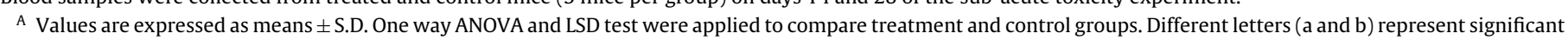
differences between groups. 

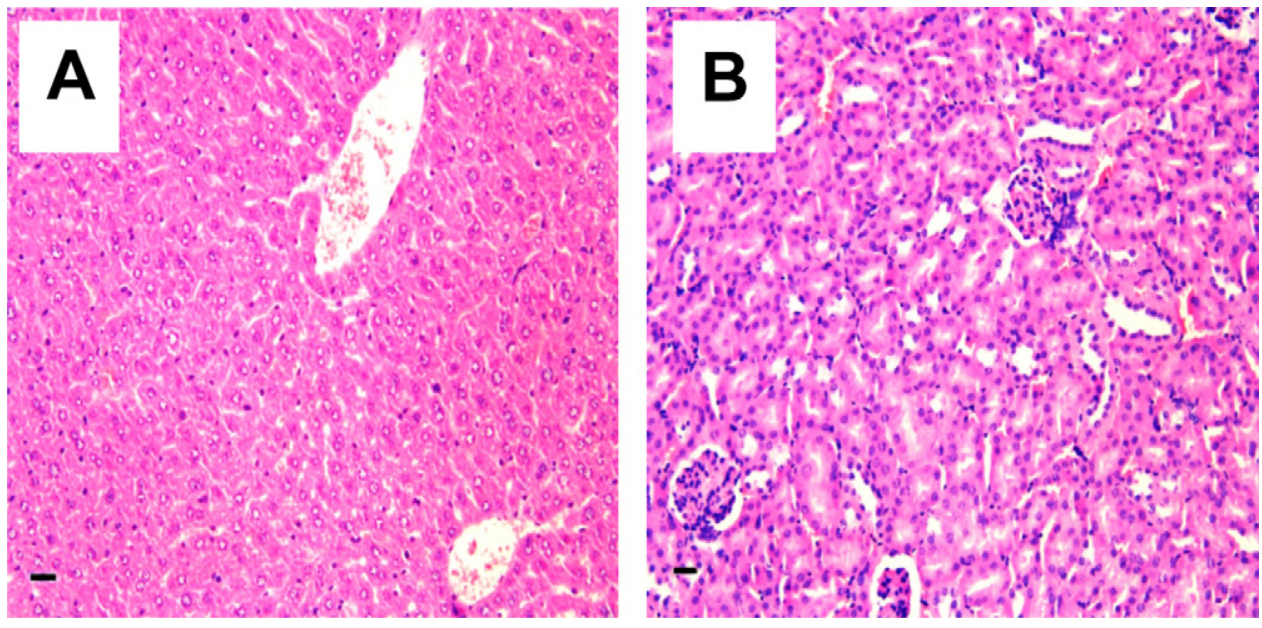

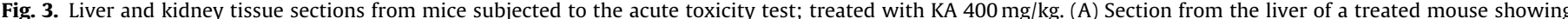

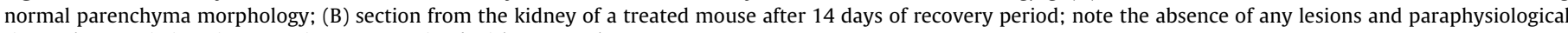
tissue characteristics. Tissue sections were stained with $\mathrm{H} \& \mathrm{E}$, scale Bar $=100 \mu \mathrm{m}$.
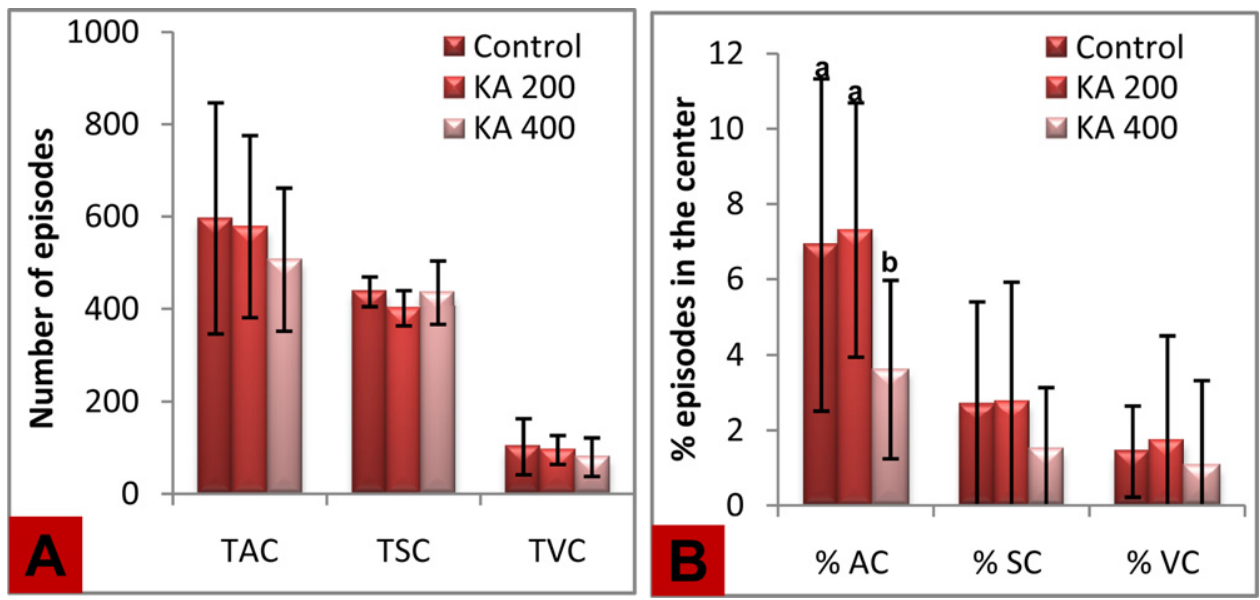

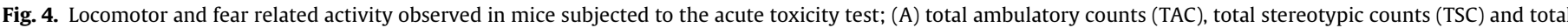

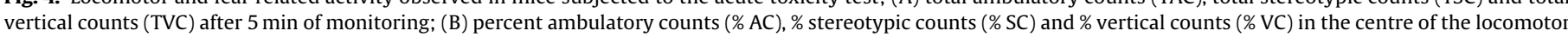

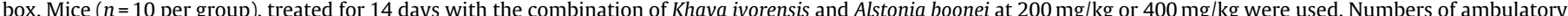

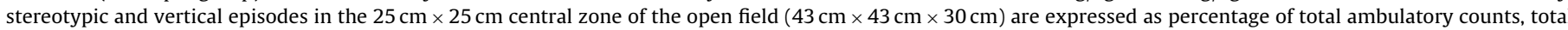

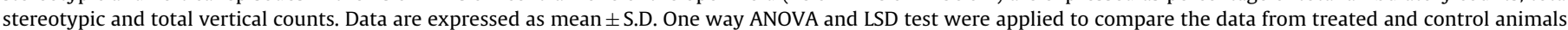
The letters $\mathrm{a}$ and $\mathrm{b}$ represent significant difference between groups.

and control mice sacrificed on day 14 and day 28, did not reveal any alterations that could be attributed to the treatments (Fig. 3 ).

3.2.2.3. Locomotor and fear related activity. Locomotor activity, in terms of frequency of movements, was not influenced by the treatment with the plant extracts (Fig. 4A). Monitoring the animals for $5 \mathrm{~min}$, the total ambulatory, total stereotypic and total vertical counts did not differ between treated and control animals.

Examining the amount of locomotor activity in the centre of the open field box in respect to total activities revealed that mice treated with $\mathrm{KA}(400 \mathrm{mg} / \mathrm{kg})$ showed a lower percentage of ambulatory counts in the centre compared with control mice and animals treated with KA at the $200 \mathrm{mg} / \mathrm{kg}$ (LSD test $p<0.05$; Fig. 4B), indicating uncomfortable, anxious feeling in these animals.

\section{Discussion}

The medicinal plants Khaya ivorensis and Alstonia boonei, popularly used in Cameroon to treat malaria patients and prevent the disease, exhibit antiplasmodial activity in the rodent malaria model. In mice kept under prophylactic treatment, parasitemia was found to be reduced by $21-53 \%$, according to dosage and plant preparation. Both plants have proved to possess antiplasmodial properties, allowing in the combination preparation additive effects to occur, that result in a parasite growth inhibition which amounts to about twice that observed with single plant administrations. Acute toxicity assessments revealed the plant combination to be safe and also prolonged treatment of mice - simulating a prophylactic treatment scheme - did not provoke any permanent alterations.

Chemical investigations on Khaya ivorensis have led to the identification of several limonoid molecules, namely proceranolide (Vanucci et al., 1992), mexicanolide, khivorin, angolensate, gedunin (Abdelgaleil et al., 2005), khayanolide, khayalactone, swietenine (Abdelgaleil et al., 2005; Zhang et al., 2009) and their derivatives. Among those tested in vitro for antimalarial activity, gedunin revealed to be the most active, showing $\mathrm{IC}_{50}$ values of $0.72 \mu \mathrm{g} / \mathrm{mL}$ (Bray et al., 1990), $1.25 \mu \mathrm{g} / \mathrm{mL}$ (Bickii et al., 2000) and $0.02-0.039 \mu \mathrm{g} / \mathrm{mL}$ (MacKinnon et al., 1997) with various $P$. $f$ strains. However, this activity could not be confirmed in vivo. Bray et al. (1990) and Omar et al. (2003) did not find any parasitemia suppressive effects in mice treated with gedunin, possibly due to poor 
absorption and/or scarce bioavailability of the pure compound in the plasma (Omar et al., 2003). In our study, using a crude aqueous plant extract, likely to contain different biologically active components, antiplasmodial activity was found to be conserved in the rodent host. Indeed, parasite growth in mice treated with $\mathrm{K}$ preparation at daily dosages of $400 \mathrm{mg} / \mathrm{ml}$ was found to be reduced by 35.5\%.

Antiplasmodial activity was evidenced also in the aqueous extract of Alstonia boonei (A). Administered at $400 \mathrm{mg} / \mathrm{kg}$ to mice, a reduction of parasitemia by $21 \%$ was observed. This result is consistent with data from in vitro and in vivo studies carried out with crude ethanolic extracts of Alstonia boonei stem bark. At a concentration of $10-20 \mu \mathrm{g} / \mathrm{ml}$, the ethanolic plant preparation was found to inhibit P.f parasite growth in vitro by $50 \%$ (Bello et al., 2009) and in vivo experiments, recently reported by lyiola et al.(2011), demonstrated significant, dose dependent reductions of Plasmodium berghei parasite development in mice. In particular, oral administration at the doses of 100,200 and $400 \mathrm{mg} / \mathrm{kg}$, reduced parasitemia values by $34-82 \%$. A $60.7 \%$ reduction was reported in mice subjected to the prophylactic test (Peters protocol) and treated at a daily dosage of $400 \mathrm{mg} / \mathrm{kg}$ (Iyiola et al., 2011). The higher activity values recorded by Iyiola et al. (2011) compared with ours may be explained on the basis of the different prophylactic treatment procedures adopted and/or by the different solvents - water versus ethanol, respectively - used for extract preparation.

$\mathrm{K}$ and $\mathrm{A}$ have been used as combination preparation for centuries in traditional cultural systems in Cameroon. Our results, showing an increased activity with the combination extract in the rodent system, are in support of the popular use of KA as a traditional antimalarial combination remedy. Comparable findings have emerged from studies on other antimalarial plant associations. Substantial enhancement of antiplasmodial in vitro activity was found with a combination of Hedyotis corymbosa and Andrographis paniculata ethanolic extracts in comparison to that observed with the single plant preparations (Mishra et al., 2009). Additionally, mice treated with the combination of the two plants showed better survival compared to the groups treated with the single plant extracts (Mishra et al., 2009). Studying interactions between aqueous extracts of Lannea schweinfurthii and Boscia salicifolia and between Turraea robusta and Sclerocarya birrea, Gathirwa et al. (2008) found that the plant combination reduced parasitemia in BALB/c mice by $54-93 \%$ compared to $40-48 \%$ in animals treated with the single plant preparations (Gathirwa et al., 2008). These study examples support the validity of the combination approach adopted by traditional medicine systems (Willcox et al., 2004).

Healers resort to multi-plant preparations believing that each plant fulfills a specific, beneficiary role in the combination. The rationale underlying plant choice for associations is multifarious not only aiming to increase anti-disease components in amount, but also to enhance their absorption, attenuate possible side effects of partner plants and/or to act against clinical signs of the disease, such as fever or nausea (Rasoanaivo et al., 2011).

In our studies, the extracts of Khaya ivorensis, Alstonia boonei and their combination proved to be safe in the acute toxicity assessments, as only reversible alterations were found in the sub-acute toxicity experiments.

In fact, no mortality was recorded up to a dose of $2779.5 \mathrm{mg} / \mathrm{kg}$ of $\mathrm{K}$, A or KA, allowing to estimate the oral median lethal dose to be higher than $2000 \mathrm{mg} / \mathrm{kg}$, amount corresponding to the $\mathrm{LD}_{50}$ value defined as practically non toxic by U.S. EPA (2006). For comparison, an $\mathrm{LD}_{50}$ value of $549 \mathrm{mg} / \mathrm{kg}$ was reported in a toxicity study conducted with a methanolic extract of Khaya ivorensis (Nwozo et al., 2006) and a $L_{50}$ of higher than $5000 \mathrm{mg} / \mathrm{kg}$ was found for an ethanolic stem bark extract of Alstonia boonei (Iyiola et al., 2011). Regarding the combination of the two plants, no data could be retrieved in literature.
Treatment with the KA extract over a period of 14 days for the assessment of sub acute toxicity did not affect red and white blood cell numbers, hematocrit and hemoglobin levels. Values of treated mice at day 28 did not differ from controls and corresponded to those reported for different laboratory mice strains by Frith et al. (1980), Festing et al. (2001), Patra et al. (2009) and by the BALB/c breeding company (Harlan laboratories, 2010). Platelet counts resulted significantly lower in mice treated with KA at $400 \mathrm{mg} / \mathrm{kg}$ with respect to both $200 \mathrm{mg} / \mathrm{kg}$ KA-treated and controls, however the values were not out of the range considered normal for BALB/c mice (Nemzek et al., 2001).

Monitoring biochemical parameters revealed some mild toxicity at the end of the 14 days gavage with KA. Liver enzymes (AST, ALT) and kidneys markers (BUN, CREA) values were found to be increased at day 14 in treated mice, however measurements performed at the end of the 14 days recovery period did not reveal differences between the two groups, indicating the reversibility of the toxic effects. Moreover, the AST, ALT, BUN and CREA values observed in treated mice on day 14 did not exceed the range of normality reported for untreated mice (6-9 week old) by Patra et al. (2009) and Harlan laboratories (2010) regarding AST and ALT values and by Oze et al. (2007) regarding BUN and CREA values. The consistently low values of GGT (3-7 U/1) observed in the treated groups further support the absence of liver damage (Uthman, 2002).

Weight measurements of livers and kidneys, as well as histological examination of sections from these organs did not reveal alterations that could be ascribed to the KA treatments. Studying toxicity of Alstonia boonei, Oze et al. (2007) found evidence of nephrotoxicity in guinea pigs after administration of an aqueous-ethanolic extract at $200 \mathrm{mg} / \mathrm{kg}$ for a period of 4 weeks. Histopathological analysis of kidney samples from treated guinea pigs revealed mild oedema, moderate hyalinization, mild to moderate increase in the size of endothelial and mesothelial cells (Oze et al., 2007).

In a study carry out with an ethanolic extract of Khaya ivorensis, accumulation of colloidal material within the liver parenchyma and the kidney tubules and glomerulus were observed in rats after administration of the extract at $500 \mathrm{mg} / \mathrm{kg} /$ day to the animals for 14 days. However, disappearance of these alterations after one week of recovery, testified the reversibility of the toxic effect (Agbedahunsi et al., 2004).

Interestingly, a methanolic stem bark extract of Alstonia boonei was found to induce anti-inflammatory, analgesic and antipyretic effects in male wistar rats (Olajide et al., 2000). Such immunomodulatory effects might be associated to the anti-malarial, febrifuge effects reported by the populations practicing the treatment with this traditional remedy.

To assess possible toxic effects of KA that can be revealed by altered animal behaviour, the open field locomotor test was carried out in this study using mice subjected to the sub-acute toxicity assessments. Overall activity, measured as number of ambulatory, stereotype and vertical movements, was not different between treated and control mice, suggesting that KA treatment did not interfere with the overall well being of the mice. However, animals treated with $400 \mathrm{mg} / \mathrm{kg}$ of the plant combination showed less activity in the open, central area of the locomotor box, indicative for reduced exploratory behaviour possibly related to anxiety sensation (Contò et al., 2005).

In summary, our preclinical studies on the KA combination provide evidence for its efficacy and safety, lending support for its traditional use for the management of malaria. Our experimental studies designed to assess the prophylactic potential of the plant combination yielded positive results. Adopting protocols which simulate real life situations, i.e. conducting prolonged prophylactic treatments of the experimental animals with dosages corresponding to those recommended by the traditional healers 
and challenging the treated mice by infective mosquito bites, KA preparations were able to reduce significantly parasitemia without eliciting permanent alterations indicative for toxicity. These results strongly encourage human clinical studies on KA to be undertaken, in order to verify whether the combination remedy, when taken by inhabitants during malaria transmission season, reduce parasite density and lead to a reduction of malaria episodes in the community.

\section{Conclusion}

In several African countries, standardized antimalarial remedies have been developed. Tea bag or syrup formulations are produced locally by pharmacists or small pharmaceutical companies and are used by the population for the treatment of malaria patients, in particular in situations in which modern drugs are not available. Prophylactic antimalarial herbal products may represent a further tool that can contribute to reduce malaria burden in communities by preventing clinical episodes and deaths. At present, the adopted strategy for malaria prevention consists in the promotion of insecticide treated nets and on intermittent treatment with modern drugs for pregnant women and small children. Chemo-prophylaxis with 'modern' drugs has shown its shortcomings when applied to entire communities, mainly related to low compliance, high cost and risk of precocious development of drug resistant Plasmodium strains. Prophylactic herbal remedies could be considered as a practicable alternative, as they are deeply rooted in the local culture, their local production allows to keep costs low and their likely content of more than one anti-plasmodial 'principle' hinders the development of resistance.

We hope that the outcomes of this study on the antimalarial activity of the KA combination remedy will motivate the implementation of clinical studies in Cameroon to validate its prophylactic efficacy at community level, thus allowing the National health policy makers to take informed decisions on the opportunity to integrate prophylactic remedies as a complementary measure within the National Malaria Control Program.

\section{Acknowledgments}

Our sincere thanks to all the people who have contributed to this study. The work received financial support by the University of Camerino (UNICAM), the Italian Malaria Network, the 7th Framework Programme of the European Commission (project 'TransMalariaBloc' n. 223736), the UNICAM PhD Programme on Malaria and Human Development, supported by WHO Global Malaria Programme and the Italian Ministry for Education, University and Research (MIUR; PRIN 2008 prot. 20084MMXNM_003: Antimalarial Lead Compounds from Nature: Isolation, Optimization and Biological Evaluation).

\section{References}

Abdelgaleil, S.A.M., El-Aswad, A.F., 2005. Antifeedant and growth inhibitory effects of tetranortriterpenoids isolated from three meliaceous species on the cotton leafworm, Spodoptera littoralis (Boisd). Journal of Applied Sciences Research 1, 234-241.

Abdelgaleil, S.A.M., Hashinaga, F., Nakatani, M., 2005. Antifungal activity of limonoids from Khaya ivorensis. Pest Management Science 61, 186-190.

Adomi, P.O., Umukoro, G., 2010. Antibacterial activity of aqueous and ethanol crude extracts of the root barks of Alstonia boonei and preliminary phytochemical test of Morinda lucida. Journal of Medicinal Plants Research 4, 644-648.

Agbedahunsi, J.M., Fakoya, F.A., Adesanya, S.A., 2004. Studies on the antiinflammatory and toxic effects of the stem bark of Khaya ivorensis (Meliaceae) on rats. Phytomedicine $11,504-508$.

Akinmoladun, A.C., Ibukun, E.O., Afor, E., Akinrinlola, B.L., Onibon, T.R., Akinboboye, A.O., Obuotor, E.M., Farombi, E.O., 2007. Chemical constituents and antioxidant activity of Alstonia boonei. African Journal of Biotechnology 6, 1197-1201.
Bello, I.S., Oduola, T., Adeosun, O.G., Omisore, N.O.A., Raheem, G.O., Ademosun, A.A., 2009. Evaluation of antimalarial activity of various fractions of Morinda lucida leaf extract and Alstonia boonei stem bark. Global Journal of Pharmacology 3, 163-165.

Bickii, J., Njifutie, N., Foyere, J.A., Basco, L.K., Ringwald, P., 2000. In vitro antimalarial activity of limonoids from Khaya grandifoliola C.D.C. (Meliaceae). Journal of Ethnopharmacology 69, 27-33.

Bray, D.H., Warhurst, D.C., Connolly, J.D., O’Neill, M.J., Phillipson, J.D., 1990. Plants as source of antimalarial drugs. Part 7. Activity of some species of Meliaceae plants and their constituents limonoids. Phytotherapy Research 4, 29-35.

CE-FAO, 1999. Données statistiques des produits forestiers non-ligneux du Cameroun. 36 p.

Contò, M.B., De Carvalho, J.G., Benedito, M.A., 2005. Behavioral differences between subgroups of rats with high and low threshold to clonic convulsions induced by DMCM, a benzodiazepine inverse agonist. Pharmacology Biochemistry and Behavior 82, 417-426.

Dondorp, A.M., Nosten, F., Yi, P., Das, D., Phyo, A.P., Tarning, J., Lwin, K.M., Ariey, F., Hanpithakpong, W., Lee, S.J., Ringwald, P., Silamut, K., Imwong, M., Chotivanich, K., Lim, P., Herdman, T., An, S.S., Yeung, S., Singhasivanon, P., Day, N.P.J., Lindegardh, N., Socheat, D., White, N.J., 2009. Artemisinin resistance in plasmodium falciparum malaria. The New England Journal of Medicine 361, 455-467.

Elisabetsky, E., Costa-Campos, L., 2006. The alkaloid alstonine: a review of its pharmacological properties. Evidence-based Complementary and Alternative Medicine 3, 39-48.

Festing, M.F.W., Diamanti, P., Turton, J.A., 2001. Strain differences in haematological response to chloramphenicol succinate in mice: implications for toxicological research. Food and Chemical Toxicology 39, 375-383.

Frith, C.H, Suber, R.L., Umholtz, R., 1980. Hematologic and clinical chemistry findings in control BALB/c and C57BL/6 mice. Laboratory Animal Science 30 $835-840$.

Gabe, M., 1968. Histological Techniques. Masson et Companie, Paris, France, 1106.

Gathirwa, J.W., Rukunga, G.M., Njagi, E.N.M., Omar, S.A., Mwitari, P.G., Guantai, A.N. Tolo, F.M., Kimani, C.W., Muthaura, C.N., Kirira, P.G., Ndunda, T.N., Amalemba, G., Mungai, G.M., Ndiege, I.O., 2008. The in vitro anti-plasmodial and in vivo antimalarial efficacy of combinations of some medicinal plants used traditionally for treatment of malaria by the Meru community in Kenya. Journal of Ethnopharmacology 115, 223-231.

Harlan laboratories, 2010. Research models and services: BALB/c data sheet, Barrier 600 and 2 - Netherlands - www.harlan.com.

Idu, M.D., Erhabor, O.J., Efijuemue, M.H., 2010. Documentation on medicinal plants sold in markets in Abeokuta, Nigeria. Tropical Journal of Pharmaceutical Research 9, 110-118.

Iyiola, O.A., Tijani, A.Y., Lateef, K.M., 2011. Antimalarial activity of ethanolic stem bark extract of Alstonia boonei in mice. Asian Journal of Biological Sciences 4 , 235-243.

Levay, E.A., Paolini, A.G., Govic, A., Hazi, A., Penman, J., Kent, S., 2008. Anxietylike behaviour in adult rats perinatally exposed to maternal calorie restriction. Behavioural Brain Research 22, 164-172.

Lucantoni, L., Yerbanga, R.S., Lupidi, G., Pasqualini, L., Esposito, F., Habluetzel, A 2010. Transmission blocking activity of a standardized neem (Azadirachta indica) seed extract on the rodent malaria parasite Plasmodium berghei in its vector Anopheles stephensi. Malaria Journal 9, 66.

MacKinnon, S., Durst, T., Arnason, J.T., Angerhofer, C., Pezzuto, J., Sanchez-Vindas, P.E., Poveda, L.J., Gbeassor, M., 1997. Antimalarial activity of tropical Meliaceae extracts and gedunin derivatives. Journal of Natural Products 60, 336-341.

Mishra, K., Dash, A.P., Swain, B.K., Dey, N., 2009. Anti-malarial activities of Andrographis paniculata and Hedyotis corymbosa extracts and their combination with curcumin. Malaria Journal 8, 26.

Nemzek, J.A., Bolgos, G.L., Williams, B.A., Remick, D.G., 2001. Differences in normal values for murine white blood cell counts and other hematological parameters based on sampling site. Inflammation Research 50, 523-527.

Neuwinger, H.D., 1996. African ethnobotany: poisons and drugs. In: Chemistry, Pharmacology, Toxicology. Chapman \& Hall Ltd., London, United Kingdom, p. 941.

Nwozo, S.O., Ajaiyeoba, E.O., Oladeinde, F.O., Olanrewaju, I., 2006. In vivo animal model toxicological studies of Nigerian medicinal plants. II. Eniantha chlorantha and Khaya ivorensis. European Journal of Scientific Research 14, 133-138.

OECD Guidelines 407 for the Testing of Chemicals, 1995. Revised 18 December 2007. Repeated Dose 28-day Oral Toxicity Study in Rodents.

Olajide, O.A., Awe, S.O., Makinde, J.M., Ekhelar, A.I., Olusola, A., Morebise, O., Okpako, D.T., 2000. Studies on the anti-inflammatory, antipyretic and analgesic properties of Alstonia boonei stem bark. Journal of Ethnopharmacology 71, 179-186.

Omar, S., Zhang, J., MacKinnon, S., Leaman, D., Durst, T., Philogene, B.J., Arnason, J.T., Sanchez-Vindas, P.E., Poveda, L., Tamez, P.A., Pezzuto, J.M., 2003. Traditionallyused antimalarials from the Meliaceae. Current Topics in Medicinal Chemistry 3, 133-139.

Oze, G.O., Nwanjo, H.U., Onyeze, G.O., 2007. Nephrotoxicity caused by the extract of Alstonia boonei (De Wild) stem bark in guinea pigs. The Internet Journal of Nutrition and Wellness 3, 40-50.

Patra, C.R., Moneim, S.S.A., Wang, E., Dutta, S., Patra, S., Eshed, M., Mukherjee, P., Gedanken, A., Shah, V.H., Mukhopadhyay, D., 2009. In vivo toxicity studies of europium hydroxide nanorods in mice. Toxicology and Applied Pharmacology 240, 88-98.

Prut, L., Belzung, C., 2003. The open field as a paradigm to measure the effects of drugs on anxiety-like behaviours: a review. European Journal of Pharmacology 463, 3-33. 
Rasoanaivo, P., Wright, C.W., Willcox, M.L., Gilbert, B., 2011. Whole plant extracts versus single compounds for the treatment of malaria: synergy and positive interactions. Malaria Journal 10, S4.

River, C., 2010. Research models and services. Italia. p. 25. "www.criver.com".

Titanji, V.P.K., Zofou, D., Ngemenya, M.N., 2008. The antimalarial potential of medicinal plants used for the treatment of malaria in Cameroonian folk medicine. African Journal of Traditional, Complimentary and Alternative Medicines 5, 302-321.

Thompson, W.R., Weil, C.S., 1952. On the construction of tables for moving average interpolation. Biometrics 8, 51-54.

U.S. EPA (Environmental Protection Agency), 2006. International classification schemes for environmental effects.

Uthman, E.O., 2002. Interpretation of Lab Test Profiles. Available at: http://web2.airmail.net/uthman/lab_test.html.
Vanucci, C., Lange, C., Lhommet, G., Dupont, B., Davoust, D., Vauchot, B., Clement, J.L., Brunk, F., 1992. An insect antifeedant limonoid from seed of Khaya ivorensis. Phytochemistry 31, 3003-3004.

White, N.J., 1998. Drug resistance in malaria. British Medical Bulletin 54, 703-715.

White, N.J., 2004. Antimalarial drug resistance. Journal of Clinical Investigation 113, 1084-1092.

Willcox, M., Bodeker, G., Rasoanaivo, P., 2004. Traditional medicinal plants and malaria. In: Traditional Herbal Medicines for Modern Times. CRC Press, New York.

World Health Organization (WHO)/World Malaria Report 2009. Geneva.

World Health Organization (WHO)/World Malaria Report 2010. Geneva.

Zhang, B., Yang, S.-P., Yin, S., Zhang, C.-R., Wu, Y., Yue, J.-M., 2009. Limonoids from Khaya ivorensis. Phytochemistry 70, 1305-1308. 